\title{
The Day Of The Week Effect: An Analysis Of The Johannesburg Stock Exchange Top 40 Firms
}

James Plimsoll, University of Cape Town, South Africa

Ben Saban, University of Cape Town, South Africa

Andreas Spheris, University of Cape Town, South Africa

Kanshukan Rajaratnam, University of Cape Town, South Africa

\begin{abstract}
This study investigates the existence of the Day of the Week (DoW) effect on returns and volatility on the Johannesburg Stock Exchange (JSE), with a specific focus on the market's Top 40 firms (Top40). It is the most 'micro' analysis of the DoW effect conducted to date, as previous literature has only explored the effect on market and index levels. While this paper focuses on a firm-specific level, it also makes a comparison with the DoW effect on the All-Share Index (ALSI) and Top40 Index (TOPI).

Drawing on Borges' (2009) study, this paper investigates whether a DoW effect exists on a specific day compared with the rest of the week. This is achieved by regressing returns on each day of the week separately. GARCH estimation models are used to test for a DoW effect with regards to variance in share returns. The initial findings show that neither the ALSI nor the TOPI have any significant DoW effects. However, a more micro examination reveals that ten of the Top40 firms have significant DoW effects on at least one day of the week. The investigation reveals no significant DoW effects with regards to volatility, which highlights that the constituents of the Top40 typically achieve consistent returns compared to other listed companies.
\end{abstract}

Keywords: Calendar Effects; South African Top40 Index; Johannesburg Stock Exchange

\section{INTRODUCTION}

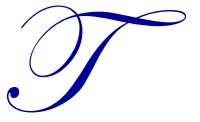

his paper investigates the existence of the DoW anomaly on the Top40 firms of the JSE. As an example of a calendar anomaly, the DoW effect is the phenomenon where stock returns and volatilities behave differently on different days of the week. Globally, calendar anomalies are well documented by, amongst others, academics such as Kiymaz \& Berument (2003), Borges (2009) and Mbulula \& Chipet (2012). These authors were able to conclude that calendar anomalies were present in their respective studies. There were, however, differences in the extent to which these anomalies can be exploited, which were largely attributable to differences in the levels of efficiency in the markets analysed.

The existence of market anomalies disproves the Efficient Market Hypothesis (EMH) which states that markets are informationally efficient and therefore excess returns cannot be achieved consistently. Studies conducted by Hadassin (1976), Cubbin et al (2006), Hoffman (2010) and others proved the existence of anomalies on the JSE and hence disproved the EMH in South Africa. Mbululu \& Chipet's (2012) study on the JSE's nine sector indices found only one sector (Basic Materials) to show significant evidence of the DoW effect. They suggested testing for the effect at a firm-specific level.

This paper investigates at a firm-specific level and is the most micro investigation of the DoW effect to date. The JSE's Top40 were selected due to their significant market concentration on the JSE and hence greater weightings in the market. These Top40 are often regarded and referred to as 'blue chip' firms. By definition, a 'blue 
chip' firm has sound and consistent business practices, and has a strong balance sheet. With regards to returns, a 'blue chip' firm has minimum volatility relative to the stock market. Volatility is an important consideration since investors and firms are not solely concerned with returns - risk is crucial to the investment decision.

This study's hypothesis, therefore, is that the DoW effect exists on the Top40 for both share returns and volatilities and it aims to investigate the extent of this existence. This will be explored using the appropriate data analysis and regression models described below. The research conducted covers the last ten years of share price returns for all the firms in the Top40. An evident limitation on the research is that the constituents of the Top40 change over time. This is accounted for and explained in the methodology section of this paper. In addition, the TOPI was only introduced as an index when the JSE officially launched FTSE/JSE African Index Series on the $24^{\text {th }}$ June 2002 (JSE, 2012). This further justifies the ten-year research period.

What follows is a comprehensive breakdown of the previous literature that has been studied for the purpose of this paper. The appropriate method and approach is then explained and employed before the outcomes are presented in the Results section. Thereafter, the conclusions and interpretations made from the results are described and avenues for further research are recommended.

\section{LITERATURE REVIEW}

The JSE's efficiency, the existence of anomalies, and the DoW effect have been investigated in a number of previous papers. This study examines the most relevant of these, drawing on the most important information from them. A combination of methodologies from these papers is tailored for this firm-specific investigation on the Top 40 and the existence of anomalies and efficiency are discussed as validation for the study.

Jammine \& Hawkins (1974) and Hadassin (1976) were some of the first to investigate the JSE's efficiency by testing the Random Walk hypothesis. Jammine \& Hawkins (1974) looked at weekly data of six share price indices for a seven-year period and analysed the weekly changes in the data. Hadassin (1976) investigated the price and earnings behaviour of JSE firms by analysing daily closing prices and price changes. Both concluded that the Random Walk hypothesis and, hence, the EMH, did not hold. Their findings thus purported that the JSE was not efficient. In contrast, Gilbertson \& Roux (1977) tested the semi-strong form of price efficiency and ultimately found the JSE to be efficient, stating that there was not enough evidence to disprove the EMH. This finding poses a potential threat to the grounds on which this investigation of the DoW effect is based, as a lack of market efficiency is a prerequisite for any market anomaly to exist.

Subsequently, Strebel (1978) critically assessed Gilbertson \& Roux's paper and argued that the EMH was, at best, half true and that part of the reason for the JSE not being efficient was due to the presence of thin trading (the impact of low trading volume) and that previous studies have not taken this into account. More recently, and thus more relevant to this paper, Cubbin et al (2006) followed up on De Bondt \& Thaler's (1985) paper in the testing of mean reversion on the JSE as a means of disproving the EMH. They found that mean reversion was significantly evident in share returns and that the JSE was predictable to a degree. This is a positive finding for the purposes of this DoW effect investigation.

Furthermore, Van Rensburg \& Robertson (2003) investigated the JSE's history based on time-series and cross-sectional correlations and analysed the presence of anomalies in the market. They concluded that the EMH did not hold as a result of certain anomalies being present. The book-to-market ratio was found to have a positive relationship with returns, while an inverse relationship was found between market capitalization and returns. Hoffman (2010) further assessed the existence of a number of anomalies on the JSE market.

In line with the Van Rensburg study, it was found that statistically significant relationships existed between a share's returns and its size, market capitalisation, and book-to-market ratio. Hoffman (2010) concluded that the EMH did not hold and that anomalies were present on the JSE. This reaffirms that market anomalies can exist on the JSE and provides scope for the investigation of the DoW effect. 
On a broader scale, Dubois \& Louvet (1996) investigated international evidence of the DoW effect across a range of markets of different stages of development. Eleven indices were selected from nine different countries for the period 1969-1992 and the authors employed a standard and moving average approach on time-series data. The DoW effect was found to disappear in the USA in recent periods, yet it is still evident in some European countries and Hong-Kong. The period assessed in Dubois \& Louvet's (1996) paper corresponded with a time when financial markets were less efficient than they are today due to globalisation. As a result, caution must be taken when making inferences based on their findings as they could be significantly different from more recent studies, which are based on today's more efficient markets.

In line with the above notion, Borges (2009) critiqued previous studies of the DoW effect and concluded that calendar anomalies, such as the DoW effect, were most prominent between the 1970s and 1990s. However, since then, the anomalies have weakened, perhaps due to increases in market efficiency across the globe. The paper highlighted that many previous studies were flawed in their methodologies and that the DoW effect was not evident on a worldwide level, but rather within certain countries' markets. Crucially, Borges suggested an important avenue of research - to investigate the DoW effect on firms, instead of indices, which thus allows for the effects of firm characteristics. Therefore, this investigation of the DoW effect explores Borges' suggestion.

While the international evidence of the DoW effect is important, the JSE has some distinct characteristics differentiating it from other markets. For this reason, Mbululu \& Chipet's (2012) study on the JSE's nine sector indices was scrutinized for local evidence of the DoW effect. They also highlighted that for anomalies to exist, there have to be occurrences that dispute the EMH. The conclusion drawn was that all but one of the nine sectors (Basic Materials sector) failed to show significant evidence of the DoW effect. Notably, however, the authors stipulated that stronger evidence of the effect may be found on a more 'micro' than 'macro' scale, reiterating the pertinence of our investigation of the firm-specific effect.

Having confirmed empirical evidence of the DoW effect, as well as the inefficiencies of the JSE, an appropriate methodology is needed for the calculation of the DoW effect on a firm-specific level in the JSE. This study draws on the methodology from the work of Basher \& Sadorsky (2006) in its use of comparisons between different levels of specificity. Basher \& Sadorsky (2006) compared the DoW effect on 21 emerging national markets and compared these results to the DoW effect on the Morgan Stanley Capital International World Index (MSCIWI). Our study uses the same principle, but scales it down to the JSE's Top40 and the ALSI and TOPI as comparators, respectively.

The calculation of returns in this paper's methodology was drawn from the studies by Miralles \& Miralles (2000), Kiymaz \& Berument (2003), and Caro et al (2006). These papers also approximated the DoW effect with a regression using four dummy variables. One day of the week was omitted so as to avoid multicollinearity, which is defined as correlation between independent variables. Importantly, Borges (2009) critiqued this approach, stating that this method only inferred whether a DoW effect exists relative to one other day (the omitted day) as opposed to all other days of the week. She subsequently proposed an estimation of five different models - one model for each day of the week.

Engle (1982), Bera \& Higgins (1993), and Bollerslev (1986) identified flaws in the use of OLS and standard regressions for the calculation of an anomaly like the DoW effect. This is because OLS regressions assume that the data are normally distributed, serially uncorrelated, and has a constant variance. These issues are addressed and accounted for by using ARCH and GARCH models in the estimation of returns to allow for changing error variances.

For the purpose of robustness, the DoW effect must be isolated and cleaned of other factors that may influence daily returns and volatilities. Historically, there has been documentation of the misrepresentation of shareholder returns because of the inclusion of dividends in those returns calculations. Van Rensburg et al (1997) argued this case, suggesting that dividends should be included in returns calculations on their 'ex-dividend' date, as opposed to their payment date. They said the overwhelming majority of studies that include dividends in returns calculations do so on the date that the shareholders are paid. The return, however, is actually realised by shareholders on the ex-dividend date in the dividend payment process. The methodology in their paper was used to clean our data and investigate the DoW effect in a robust manner. 
Calendar effects, such as DoW, have been shown to have dissipated internationally in recent years, but most of the empirical evidence has been based on index levels and on markets that are generally more efficient than the JSE. The research of previous literature has identified the niche for the investigation in South Africa of the DoW effect on a firm-specific level. This is the first study in South Africa to assess the effect on both share returns and volatilities on a firm-specific level.

\section{DATA AND METHODOLOGY}

\section{Data}

The data, downloaded from Datastream, comprises of the daily closing prices of the Total Return Index for the individual Top40 firms, the ALSI, and the TOPI from 26 July, 2002, to 27 July, 2012. The data for the Top40 comprise of the firms present at 27 July, 2012, and does not vary based on its historical composition. For both of the indices, as well as the Top40 firms, the Total Return Price Index data were used.

The Total Return Price Index data were selected as opposed to the Price Index data because it includes reinvested dividends when calculating the share price return. The raw Price Index data reflect changes in the share price but does not include any reinvestment of dividends. As a result, fluctuations in the share price may be as a result of ex-dividend date declarations. Therefore, to isolate the DoW effect, the ex-dividend day effect must be eliminated, which is achieved by employing the Total Return Index.

In the Total Return Index equation, as described by DataStream, the dividend paid by the firm is added to the price on the payment ex-date:

where:

$$
R I_{t}=R I_{t-1} \times \frac{P_{t}+D_{t}}{P_{t-1}}
$$

- $\quad P_{t}$ is price on the ex-dividend date of the share

- $\quad P_{t-1}$ is the price of the share on the previous day

- $D_{t}$ is the dividend payment associated with the ex-dividend date

In addition, share prices reported on public holidays, where no trading had occurred, were removed from the dataset. The share's closing price on these days of no trade was the same as the close on the previous day. This therefore resulted in artificial zero returns for each firm on the day of each public holiday. This can significantly distort results over a period as long as ten years. All public holidays were thus removed from the data by eliminating them completely. A list of the South African public holidays is as follows:

\section{$\underline{\text { SA National Holidays }}$}

New Year's Day

Human Rights Day

Good Friday

Family Day

Freedom Day

Workers' Day

Youth Day

National Women's Day

Heritage Day

Day of Reconciliation

Christmas Day

Day of Goodwill

\section{Date}

01 January

23 march

Friday before Easter Sunday

Monday after Easter Sunday

27 April

01 May

16 June

09 August

24 September

16 December

25 December

26 December 
Finally, the companies, Growthpoint Properties Ltd. and Assore Ltd, were removed from the dataset due to thin trading. Similar to that of the holiday effect, the consequence of thin trading is artificial zero share returns. This, again, hinders the detection of any legitimate DoW effect for these firms. Therefore, the methodology that follows uses data that have been cleaned of the ex-dividend day effect, the public holiday effect, and thin trading.

\section{METHODOLOGY}

\section{Percentage Price Return Analysis}

Returns are calculated in South African Rands as:

$$
r_{t}=\ln \left(\frac{P_{t}}{P_{t-1}}\right)
$$

where:

- $\quad r_{t}$ is the daily percentage return of the share at time $\mathrm{t}$

- $\quad P_{t}$ is the current closing price of the share at time $\mathrm{t}$

- $\quad P_{t-1}$ is the closing share price at time t-1

As mentioned in the Literature Review section, Borges' (2009) paper provided the methodology that best fits the desired methodology of this study - to compare the DoW effect of each day with the rest of the week. The initial analysis began by regressing the daily percentage share price returns with a dummy variable representing each day of the week. This yielded the following regression equation:

$$
r_{t}=\alpha+B_{i} D_{i t}+\epsilon_{t}
$$

where:

- $\quad r_{t}$ is the daily percentage return of the share at time $\mathrm{t}$

- $\quad D_{i t}$ is an indicator variable for either Monday, Tuesday, Wednesday, Thursday, Friday at time $\mathrm{t}$

- $\epsilon_{t}$ is the error term

However, using the regular Ordinary Least Squares (OLS) regression method to test for a DoW effect has its flaws. The OLS estimation assumes that the data were normally distributed, serially uncorrelated, and has a constant variance. To solve the autocorrelation problem, a lagged variable of returns (in this case, returns on a weekday) was included in the model, as suggested by Kiymaz \& Berument (2003). This explicitly allows each day's returns to be explained by both the original indicator variable and the lagged dependent variable, which mitigates autocorrelation in the residual term. This resulted in the following regression equation:

where:

$$
r_{t}=\alpha+B_{i} D_{i t}+\sum_{i=1}^{n} \alpha_{i} R_{t-i}+\epsilon_{t}
$$

- $\quad r_{t}$ is the daily percentage share return at time $\mathrm{t}$

- $\quad D_{i t}$ is an indicator variable for either Monday, Tuesday, Wednesday, Thursday, Friday at time $\mathrm{t}$

- $\mathrm{n}$ is the lag order ${ }^{1}$

\footnotetext{
${ }^{1}$ In order to determine $\mathrm{n}$, the final prediction error criteria (FPEC) was used, which eliminates autocorrelation in the residual term. 


\section{Volatility Analysis}

Volatility is a descriptor of risk. The way this study interprets volatility is by assessing the variance in returns. The intuitive method of identifying whether volatility is significant on each day of the week is by regressing the residuals on the indicator variables. This would explain how much of the residual variance is explained by each day of the week.

However, in an inefficient market, variances tend to not be constant. Thus, in this investigation, the Generalised Autoregressive Conditional Heteroskedascity (GARCH) model, proposed by Bollerslev (1986), was implemented in order to solve the problem of non-constant variances. The implementation of this method takes the historical standard deviation into account when forecasting volatility and allows the weights on the residuals to decrease over time.

The equation structure for estimated variance looks like:

$$
\sigma_{t}^{2}=\alpha_{0}+\alpha_{2} D_{i t}+\sum_{i=1}^{q} \alpha_{i} \varepsilon_{t-i}^{2}+\sum_{i=1}^{p} \gamma_{i} \sigma_{t-i}^{2}
$$

where:

- $\quad \sigma_{t}^{2}$ is the standard deviation at time $\mathrm{t}$

- $\quad D_{i t}$ is an indicator variable for either Monday, Tuesday, Wednesday, Thursday, Friday at time $\mathrm{t}$

- $\quad p$ and $q$ are autoregressive polynomials

\section{RESULTS}

\section{Descriptive Statistics}

Descriptive statistics provide an insight into the characteristics of the dataset being used. Table 1 in the Appendix reports the descriptive statistics for the ALSI, TOPI, and all of the Top40 firms for the entire sample for the ten-year period. The table illustrates that, overall, mean returns are generally positive, with the exception of Capital Shopping Centres Group PLC (-0.006\%) and Harmony Gold Mining Company Ltd. (-0.0059\%). The highest returns are seen for Kumba Iron Ore Ltd. $(0.1380 \%)$ and the lowest for Capital Shopping Centres Group PLC ($0.006 \%)$.

Both the ALSI and TOPI are negatively skewed and have a high kurtosis value. This means that while the indices' returns are generally positive, the high kurtosis indicates scope for extreme return values.

Twenty-eight of the Top40 are positively skewed, indicating that the bulk of the values lie to the left of the mean. All the firms exhibit high levels of kurtosis ('fatter' distribution tails), particularly Compagnie Financiere Richemont SA (19.26321), which shows that more of the variance in returns is due to infrequent extreme values, as opposed to frequent moderate values.

Several of the firms in the Top 40 have a different number of daily observations. This is due to the different listing dates of the individual Top40 firms over the ten-year period. Vodacom Group Ltd., for example, listed on the JSE on 18 May, 2009, has 834 daily observations compared to Absa Group Ltd.'s 2,502 daily observations. However, this does not distort the results, as the Top40 is defined above as the group of constituent firms present as of 27 July, 2012.

\section{Day of the Week Returns}

Table 2 in the Appendix shows the mean returns for the ALSI, TOPI, and all of the Top40 firms for each day of the week. It serves to illustrate any patterns that may be present in the mean daily returns in the Top 40 . The grey shading in the table indicates mean daily returns that are greater than a selected benchmark of $0.1 \%$. 
The firms are grouped into three categories - Industrials, Resources and Financials. This provides an initial indication as to whether firms within each of the three categories display, on average, positive or negative returns on specific days of the week. An excerpt of Table 2 shows that the Financials category illustrates mostly high positive average returns on Tuesday and Wednesday and negative average returns on Friday. There is also an evident trend in the Resources category where negative daily returns are generally seen on Tuesday.

\begin{tabular}{|l|c|c|c|c|c|}
\hline Excerpts from Table 2: Financials & & & & \\
\hline & Monday & Tuesday & Wednesday & Thursday & Friday \\
\hline Remgro Ltd & $0.12 \%$ & $0.03 \%$ & $0.11 \%$ & $0.20 \%$ & $0.01 \%$ \\
\hline ABSA Group Ltd & $0.12 \%$ & $0.14 \%$ & $0.12 \%$ & $0.09 \%$ & $-0.08 \%$ \\
\hline Standard Bank Group Ltd & $0.18 \%$ & $0.15 \%$ & $0.10 \%$ & $0.03 \%$ & $-0.09 \%$ \\
\hline Nedbank Group Ltd & $0.05 \%$ & $0.05 \%$ & $0.06 \%$ & $0.14 \%$ & $-0.11 \%$ \\
\hline African Bank Investments Ltd & $0.13 \%$ & $0.14 \%$ & $0.09 \%$ & $0.09 \%$ & $0.08 \%$ \\
\hline Investec PLC & $-0.14 \%$ & $0.03 \%$ & $0.11 \%$ & $0.17 \%$ & $0.02 \%$ \\
\hline Old Mutual PLC & $0.03 \%$ & $0.10 \%$ & $0.11 \%$ & $0.05 \%$ & $-0.13 \%$ \\
\hline RMB Holdings Ltd & $-0.06 \%$ & $0.14 \%$ & $0.21 \%$ & $0.16 \%$ & $-0.02 \%$ \\
\hline Sanlam Ltd & $0.02 \%$ & $0.16 \%$ & $0.19 \%$ & $0.07 \%$ & $-0.06 \%$ \\
\hline Firstrand Ltd & $0.05 \%$ & $0.15 \%$ & $0.22 \%$ & $0.08 \%$ & $-0.10 \%$ \\
\hline
\end{tabular}

\section{Regression Results}

The results of the preliminary regressions on the ALSI and TOPI showed no significant DoW effects, which is in line with Mbululu \& Chipet's (2012) and Basher \& Sadorsky's (2006) findings that the DoW effect is not prominent on the JSE at a macro level.

Table 2 also illustrates the lack of a DoW effect on the ALSI and TOPI. While the mean returns do not represent any statistical significance, they do reiterate the regression results showing no high or low mean returns on any specific days of the week.

Figure 1 illustrates that 10 of the JSE's Top40 show statistically significant returns (at a significance level of $6 \%$ ) on certain days of the week. Next to each scatter point on the diagram, the respective beta coefficient is provided. Bidvest Group Ltd. has the most statistically significant beta coefficient (-0.00212) on a Friday. Tiger Brands Ltd. is the only firm to exhibit significant beta coefficients on two days of the week - Wednesday (0.00166) and Friday (-0.00163). What is evident from Figure 1 is the clustering of five firms on a Friday that exhibits significantly negative returns. Four out of five of these firms - ABSA Group Ltd., Firstrand Ltd., Bidvest Group Ltd., and Standard Bank Group Ltd. - all offer financial services.

When comparing the output of Figure 1 with that in Table 2, a notable observation is that the signs of the significant beta coefficients correspond with the signs of the respective mean returns. Similarly, the clustering of firms in the financial category in Table 2 corresponds with the clustering of the four financial firms from the regression output in Figure 1.

The analysis conducted on variance in returns using the GARCH method showed that no beta coefficients are statistically significant. We therefore fail to infer that any of the firms on the Top40 have a DoW effect with regard to volatility, meaning that returns for a particular share do not vary more on one day of the week than any other day. What this finding does illustrate is the plausibility of the notion of "blue chip" firms being a relatively safe equity investment option. "Blue chip" firms (those that make up the Top40), by definition, are able to perform well, even in times of economic and financial hardship, and thus are able to provide more consistent returns for their investors than other firms. This could mean less risk in the form of share return variance, as indicated by the results of the GARCH regressions conducted in this study. 


\section{CONCLUSION}

This paper examines the existence of the DoW effect on a firm-specific level, looking in particular at the JSE's Top40. The justification for this level of specificity came from the analysis of previous literature by Borges (2009) and Mbulula \& Chipeta (2012), among others, who proposed furthering their research to look at whether firm characteristics play a part in the DoW effect. The Top40 is investigated, in particular, because the JSE is a concentrated market, and thus these firms account for a large proportion of the market's share capitalisation.

The empirical evidence from the appropriate regressions above give rise to several conclusions. Having read into previous literature on the efficiency of the JSE, we establish that the market is weak-form efficient, at best, which provides scope for the existence of anomalies such as the DoW effect. It is evident that the DoW effect does not exist on the index level of the ALSI and TOPI. It does, however, exist on a firm-specific level, albeit not for each and every firm in the JSE's Top40. Ten of the Top40 firms were found to exhibit the DoW effect on at least one day of the week. This is indeed new evidence on the JSE, which is reaffirmed by the pattern indications in Table 2 .

Ultimately, this study has established that the DoW effect becomes stronger when looking at firms as opposed to indices and markets. Anomalies are only deemed useful to investors if they can consistently be exploited for financial gain. Future studies could investigate the plausibility of trading strategies based on the JSE's Top40 DoW effect, taking into consideration trading costs and other such fees.

\section{ACKNOWLEDGEMENT}

Special thanks to Prof. Paul van Rensburg, the Frank Robb Professor of Finance at the University of Cape Town, South Africa, for advising on the research.

\section{AUTHOR INFORMATION}

James Plimsoll is a graduate specialising in Finance and Economics from the University of Cape Town, South Africa. He is employed as a Debt Consultant at Intelligent Debt Management (IDM) in Cape Town. E-mail: plmjam001@myuct.ac.za

Ben Saban is a graduate of Finance from the University of Cape Town, South Africa, and is currently pursuing a new start-up called Mooibos together with Mr. Andreas Spheris. E-mail: sbnben001@ myuct.ac.za

Andreas Spheris is a graduate of Finance from the University of Cape Town, South Africa. He is currently pursuing a new start-up venture and drawing on his financial entrepreneur skills to build the business. E-mail: sphand002@myuct.ac.za

Kanshukan Rajaratnam is a Senior Lecturer of Finance and is an associate of the African Collaboration for Quantitative Finance and Risk Research (ACQuFRR) at the University of Cape Town, South Africa. His research interests lie in decision-making in consumer credit loans, modelling credit union behaviour, and the Basel Accord. $\mathrm{He}$ is a member of the Operations Research Society of South Africa (ORSSA) and Southern Africa Institute for Management Scientists (SAIMS). E-mail: kanshukan.rajaratnam@uct.ac.za (corresponding author).

\section{REFERENCES}

1. Basher, S. \& Sadorsky, P. (2006). Day-of-the-week effects in emerging stock markets. Applied Economics Letters, 13(10) 621-628.

2. Bera, A. K., \& Higgins, M. L. (1993). ARCH Models: Properties, Estimation and Testing. Journal of Economic Surveys, 7(4) 307-366.

3. Borges, M. (2009). Calendar effects in Stock Markets: Critique of Previous Methodologies and Recent Evidence in European Countries. Retrieved from: http://pascal.iseg.utl.pt/ depeco/wp/wp372009.pdf

4. Caro, A. (2006). Day of the Week effect on European Stock Markets. International Research Journal of Finance and Economics, 2. 
5. Dubois, M. \& Louvet, P. (1996). The day-of-the-week effect: The international evidence. Journal Of Banking \& Finance, 20(9) 1463-1484.

6. Engle, R. (1982). Autoregressive Conditional Heteroskedasticity with Estimates of the Variance of UK Inflation. Econometrica, 50 987-1008.

7. Johannesburg Stock Exchange (2012) Johannesburg Stock Exchange, South Africa, [Online] Retrieved from http://www.jse.co.za/Products/FTSE-JSE/FAQs.aspx

8. Kurson, K. (2002). Where Have All the Blue Chips Gone? Money 31(13) 43.

9. Kyimaz, H. \& Berument, H. (2001). The day of the week effect on Stock Market Volatility. Journal of Economics and Finance, 25(2)181-193.

10. Mbululu, D. \& Chipeta, C. (2012). Day-of-the-week effect: Evidence from the nine economic sectors of the JSE. Journal of Finance, 75 55-65.

11. Miralles, J.L. \& Miralles, M.M. (2000). An Empirical Analysis of the Weekday effect on the Lisbon Stock Market over Trading and Non-Trading Periods. Portuguese Review of FinancialMarkets, 3(2) 5-14.

12. Van Rensburg, P. \& Robertson, M. (2003). Style characteristics and the cross-section of JSE Returns. Investments Analysts Journal, 57 1-10.

13. Van Rensburg, P., Slaney, K., and Hardy, P. (1997). A note on the timing of dividend receipts in share returns. South African Journal Of Business Management, 28(4) 169. 


\section{APPENDIX 1}

Table 1: Descriptive Statistics

\begin{tabular}{|c|c|c|c|c|c|c|c|}
\hline Firms/Indices & Observations & Mean & Std. Dev. & Variance & Skewness & Kurtosis & Lags \\
\hline All Share Index (ALSI) & 2610 & $0.06 \%$ & 0.0141347 & 0.0001998 & -0.0705553 & 6.250208 & 3 \\
\hline Top 40 Index (TOPI) & 2610 & $0.06 \%$ & 0.0128995 & 0.0001664 & -0.1272803 & 6.392408 & 3 \\
\hline ABS A Group Ltd & 2502 & $0.08 \%$ & 0.187985 & 0.003534 & 0.1533548 & 5.450653 & 4 \\
\hline African Rainbow Minerals Ltd & 2490 & $0.06 \%$ & 0.025624 & 0.0006566 & -0.4039744 & 8.025064 & 4 \\
\hline African Bank Investments Ltd & 2502 & $0.11 \%$ & 0.0216968 & 0.0004708 & 0.0732323 & 4.622501 & 2 \\
\hline Anglo American PLC & 2502 & $0.03 \%$ & 0.025498 & 0.0006501 & -0.098654 & 7.140729 & 3 \\
\hline AngloGold Ashanti Ltd & 2502 & $0.02 \%$ & 0.0244004 & 0.0005954 & 0.2704943 & 6.009223 & 2 \\
\hline Anglo American Platinum Ltd & 2502 & $0.02 \%$ & 0.0270677 & 0.0007327 & -0.3328852 & 5.723391 & 3 \\
\hline Aspen Pharmacare Holdings Ltd & 2500 & $0.12 \%$ & 0.0191928 & 0.0003684 & 0.0119137 & 5.718595 & 4 \\
\hline BHP Billiton PLC & 2502 & $0.08 \%$ & 0.0238349 & 0.0005681 & 0.2444967 & 6.641281 & 3 \\
\hline Bidvest Group Ltd & 2502 & $0.07 \%$ & 0.0173552 & 0.0003012 & 0.0027705 & 5.457174 & 4 \\
\hline British American Tobacco PLC & 978 & $0.07 \%$ & 0.0127596 & 0.0001628 & 0.0500169 & 5.019737 & 2 \\
\hline Capital Shopping Centres Group PLC & 2502 & $-0.01 \%$ & 0.018002 & 0.0003241 & -0.4303585 & 7.77554 & 0 \\
\hline Exxaro Resources Ltd & 2501 & $0.12 \%$ & 0.0253153 & 0.0006409 & 0.0606119 & 8.248108 & 4 \\
\hline Firstrand Ltd & 2502 & $0.08 \%$ & 0.0201057 & 0.0004042 & -0.0803384 & 4.899089 & 4 \\
\hline Gold Fields Ltd & 2502 & $0.01 \%$ & 0.0281115 & 0.0007903 & 0.1248099 & 6.47276 & 2 \\
\hline Harmony Gold Mining Company Ltd & 2502 & $-0.01 \%$ & 0.0292764 & 0.0008571 & 0.0869169 & 6.018955 & 1 \\
\hline Impala Platinum Holdings Ltd & 2502 & $0.05 \%$ & 0.0276808 & 0.0007662 & -0.2619619 & 5.523979 & 4 \\
\hline Imperial Holdings Ltd & 2502 & $0.08 \%$ & 0.0197392 & 0.0003896 & -0.0431418 & 5.364296 & 4 \\
\hline Investec PLC & 2502 & $0.04 \%$ & 0.0227369 & 0.000517 & 0.021399 & 6.08029 & 4 \\
\hline Kumba Iron Ore Ltd & 1484 & $0.14 \%$ & 0.0266467 & 0.00071 & 0.0681198 & 5.650693 & 2 \\
\hline Massmart Holdings Ltd & 2501 & $0.12 \%$ & 0.0182798 & 0.0003342 & 0.1498695 & 5.835277 & 4 \\
\hline Mondi Ltd & 1324 & $0.02 \%$ & 0.0247929 & 0.0006147 & -0.2690648 & 6.702677 & 3 \\
\hline MTN Group Ltd & 2502 & $0.11 \%$ & 0.023334 & 0.0005445 & 0.2686204 & 5.992786 & 4 \\
\hline Naspers Ltd & 2502 & $0.14 \%$ & 0.020482 & 0.0004195 & -0.0524089 & 4.280568 & 4 \\
\hline Nedbank Group Ltd & 2502 & $0.04 \%$ & 0.0197475 & 0.00039 & 0.0239984 & 5.422938 & 4 \\
\hline Old Mutual PLC & 2502 & $0.03 \%$ & 0.0230824 & 0.0005328 & -0.1045122 & 8.955886 & 3 \\
\hline Remgro Ltd & 2501 & $0.09 \%$ & 0.015664 & 0.0002454 & 0.2413435 & 5.774403 & 4 \\
\hline Compagnie Financiere Richemont SA & 2610 & $0.07 \%$ & 0.0206736 & 0.0004274 & 1.010505 & 19.26321 & 3 \\
\hline RMB Holdings Ltd & 2502 & $0.09 \%$ & 0.0212219 & 0.0004504 & 0.0184475 & 5.078492 & 4 \\
\hline SABMiller PLC & 2502 & $0.07 \%$ & 0.0160082 & 0.0002563 & 0.0893657 & 5.364268 & 4 \\
\hline Sanlam Ltd & 2502 & $0.08 \%$ & 0.0178351 & 0.0003181 & 0.0355668 & 5.390668 & 3 \\
\hline Sasol Ltd & 2502 & $0.06 \%$ & 0.0221979 & 0.0004927 & 0.0935571 & 5.382709 & 3 \\
\hline Shoprite Holdings Ltd & 2502 & $0.14 \%$ & 0.0179967 & 0.0003239 & 0.0310022 & 4.960144 & 4 \\
\hline Standard Bank Group Ltd & 2502 & $0.07 \%$ & 0.0193298 & 0.0003736 & 0.1263438 & 5.206055 & 4 \\
\hline S teinhoff International Holdings Ltd & 2502 & $0.06 \%$ & 0.0220678 & 0.000487 & 0.2316882 & 7.233543 & 4 \\
\hline Tiger Brands Ltd & 2502 & $0.09 \%$ & 0.0149565 & 0.0002237 & 0.1607717 & 5.385843 & 4 \\
\hline Truworths International Ltd & 2502 & $0.13 \%$ & 0.0200595 & 0.0004024 & 0.0677106 & 5.373088 & 3 \\
\hline Vodacom Group Ltd & 834 & $0.10 \%$ & 0.014111 & 0.0001991 & 0.2426274 & 5.352005 & 4 \\
\hline Woolworths Holdings Ltd & 2610 & $0.13 \%$ & 0.0180841 & 0.000327 & 0.0776121 & 4.655815 & 3 \\
\hline
\end{tabular}




\section{APPENDIX 1 - continued}

Table 2: Daily Average Returns

\begin{tabular}{|c|c|c|c|c|c|}
\hline & Monday & Tuesday & Wednesday & Thursday & Friday \\
\hline \multicolumn{6}{|l|}{ Indices } \\
\hline ALSI & $0.13 \%$ & $0.02 \%$ & $0.04 \%$ & $0.08 \%$ & $0.03 \%$ \\
\hline TOPI & $0.12 \%$ & $0.03 \%$ & $0.05 \%$ & $0.08 \%$ & $0.04 \%$ \\
\hline \multicolumn{6}{|l|}{ Industrials } \\
\hline British American Tobacco PLC & $0.10 \%$ & $0.09 \%$ & $0.10 \%$ & $0.04 \%$ & $0.01 \%$ \\
\hline SABMiller PLC & $0.12 \%$ & $0.09 \%$ & $0.09 \%$ & $0.04 \%$ & $0.02 \%$ \\
\hline Mondi Ltd & $-0.05 \%$ & $-0.08 \%$ & $0.11 \%$ & $0.28 \%$ & $-0.18 \%$ \\
\hline Sasol Ltd & $0.24 \%$ & $0.00 \%$ & $-0.12 \%$ & $0.20 \%$ & $-0.01 \%$ \\
\hline Compagnie Financiere Richemont SA & $0.12 \%$ & $0.17 \%$ & $0.04 \%$ & $0.08 \%$ & $-0.04 \%$ \\
\hline Bidvest Group Ltd & $0.10 \%$ & $0.10 \%$ & $0.18 \%$ & $0.08 \%$ & $-0.09 \%$ \\
\hline Imperial Holdings Ltd & $0.08 \%$ & $0.14 \%$ & $0.13 \%$ & $0.05 \%$ & $0.00 \%$ \\
\hline Shoprite Holdings Ltd & $0.13 \%$ & $0.14 \%$ & $0.21 \%$ & $0.18 \%$ & $0.01 \%$ \\
\hline Steinhoff International Holdings Ltd & $0.12 \%$ & $0.01 \%$ & $0.03 \%$ & $0.17 \%$ & $-0.02 \%$ \\
\hline Tiger Brands Ltd & $0.10 \%$ & $0.06 \%$ & $0.22 \%$ & $0.09 \%$ & $-0.04 \%$ \\
\hline Truworths International Ltd & $0.16 \%$ & $0.14 \%$ & $0.11 \%$ & $0.12 \%$ & $0.13 \%$ \\
\hline Massmart Holdings Ltd & $0.12 \%$ & $0.09 \%$ & $0.13 \%$ & $0.12 \%$ & $0.13 \%$ \\
\hline Woolworths Holdings Ltd & $0.18 \%$ & $0.04 \%$ & $0.16 \%$ & $0.09 \%$ & $0.16 \%$ \\
\hline Naspers Ltd & $0.13 \%$ & $0.15 \%$ & $0.16 \%$ & $0.08 \%$ & $0.16 \%$ \\
\hline Mtn Group Ltd & $0.19 \%$ & $0.07 \%$ & $0.05 \%$ & $0.14 \%$ & $0.10 \%$ \\
\hline Vodacom Group Ltd & $0.25 \%$ & $0.06 \%$ & $0.24 \%$ & $-0.02 \%$ & $-0.03 \%$ \\
\hline Aspen Pharmcare Holdings Ltd & $0.10 \%$ & $0.09 \%$ & $0.16 \%$ & $0.14 \%$ & $0.13 \%$ \\
\hline Capital Shopping Centres Group PLC & $-0.04 \%$ & $-0.01 \%$ & $0.08 \%$ & $0.00 \%$ & $-0.07 \%$ \\
\hline \multicolumn{6}{|l|}{ Resources } \\
\hline Anglo American Platinum Ltd & $0.20 \%$ & $-0.09 \%$ & $0.12 \%$ & $0.03 \%$ & $-0.15 \%$ \\
\hline Harmony Gold Mining Company Ltd & $0.22 \%$ & $-0.38 \%$ & $0.07 \%$ & $0.02 \%$ & $0.04 \%$ \\
\hline Anglo American PLC & $0.10 \%$ & $-0.06 \%$ & $-0.07 \%$ & $0.10 \%$ & $0.09 \%$ \\
\hline AngloGold Ashanti & $0.08 \%$ & $-0.16 \%$ & $0.12 \%$ & $-0.08 \%$ & $0.14 \%$ \\
\hline BHP Billiton PLC & $0.16 \%$ & $0.00 \%$ & $0.01 \%$ & $0.08 \%$ & $0.13 \%$ \\
\hline Impala Platinum Holdings Ltd & $0.15 \%$ & $-0.18 \%$ & $0.21 \%$ & $0.08 \%$ & $-0.01 \%$ \\
\hline Kumba Iron Ore Ltd & $0.32 \%$ & $0.11 \%$ & $0.14 \%$ & $0.06 \%$ & $0.06 \%$ \\
\hline African Rainbow Mineral Ltd & $0.07 \%$ & $0.02 \%$ & $0.10 \%$ & $0.05 \%$ & $0.05 \%$ \\
\hline Exxaro Resources Ltd & $0.07 \%$ & $0.05 \%$ & $0.17 \%$ & $0.10 \%$ & $0.21 \%$ \\
\hline Gold Fields Ltd & $0.05 \%$ & $-0.16 \%$ & $0.19 \%$ & $-0.05 \%$ & $0.01 \%$ \\
\hline \multicolumn{6}{|l|}{ Financials } \\
\hline Remgro Ltd & $0.12 \%$ & $0.03 \%$ & $0.11 \%$ & $0.20 \%$ & $0.01 \%$ \\
\hline ABSA Group Ltd & $0.12 \%$ & $0.14 \%$ & $0.12 \%$ & $0.09 \%$ & $-0.08 \%$ \\
\hline Standard Bank Group Ltd & $0.18 \%$ & $0.15 \%$ & $0.10 \%$ & $0.03 \%$ & $-0.09 \%$ \\
\hline Nedbank Group Ltd & $0.05 \%$ & $0.05 \%$ & $0.06 \%$ & $0.14 \%$ & $-0.11 \%$ \\
\hline African Bank Investments Ltd & $0.13 \%$ & $0.14 \%$ & $0.09 \%$ & $0.09 \%$ & $0.08 \%$ \\
\hline Investec PLC & $-0.14 \%$ & $0.03 \%$ & $0.11 \%$ & $0.17 \%$ & $0.02 \%$ \\
\hline Old Mutual PLC & $0.03 \%$ & $0.10 \%$ & $0.11 \%$ & $0.05 \%$ & $-0.13 \%$ \\
\hline RMB Holdings Ltd & $-0.06 \%$ & $0.14 \%$ & $0.21 \%$ & $0.16 \%$ & $-0.02 \%$ \\
\hline Sanlam Ltd & $0.02 \%$ & $0.16 \%$ & $0.19 \%$ & $0.07 \%$ & $-0.06 \%$ \\
\hline Firstrand Ltd & $0.05 \%$ & $0.15 \%$ & $0.22 \%$ & $0.08 \%$ & $-0.10 \%$ \\
\hline
\end{tabular}




\section{APPENDIX 2}

\section{P-values: Percentage Total Price Returns}

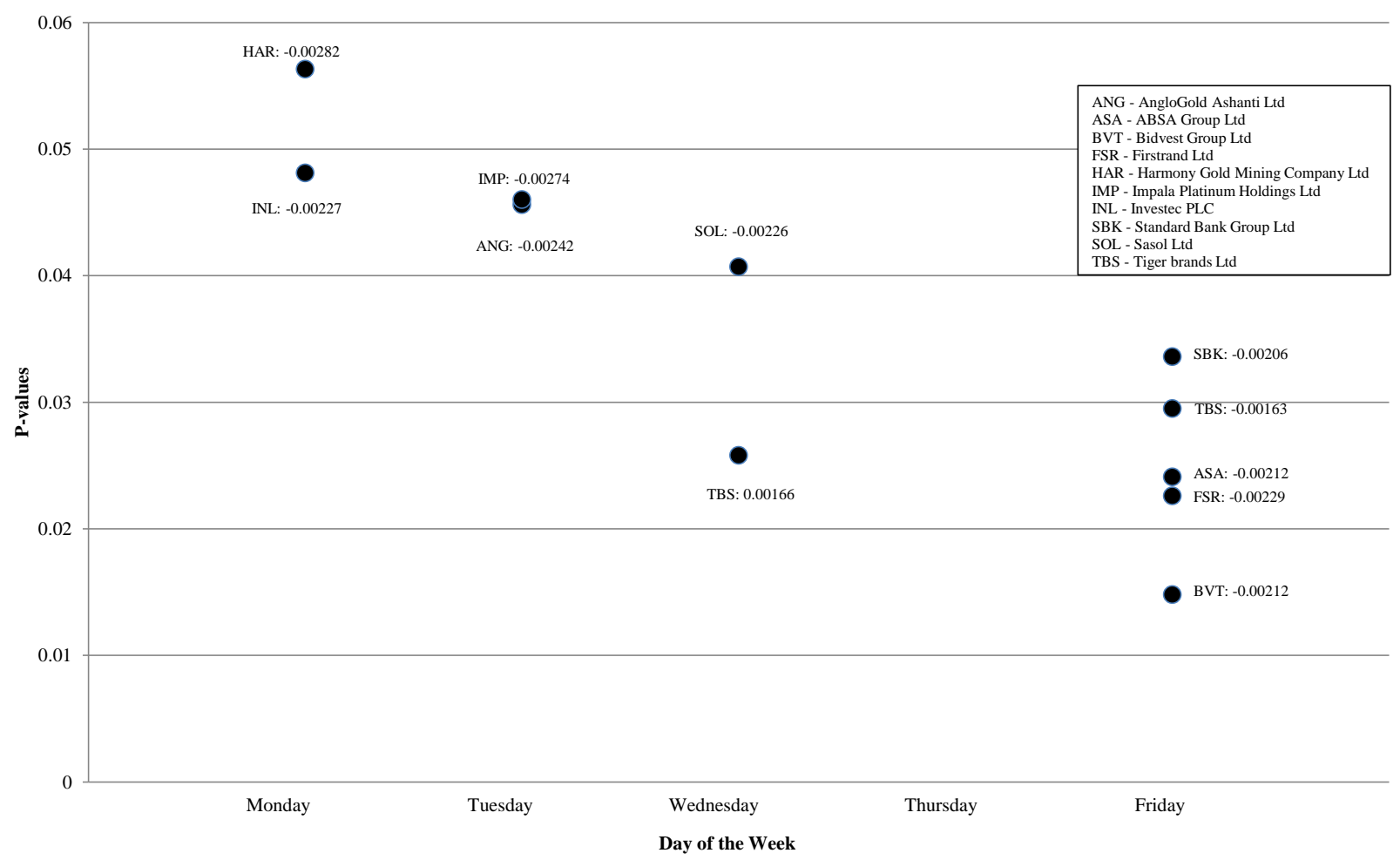

Figure 1: P-Values - Percentage Total Price Return 